\title{
Effects of Spartina detritus enrichment on aerobic/ anaerobic benthic metabolism in an intertidal sediment
}

\author{
Frede Ø. Andersen* and Barry T. Hargrave
}

Marine Ecology Laboratory, Bedford Institute of Oceanography, P.O. Box 1006, Dartmouth, N.S. B2Y 4A2, Canada

\begin{abstract}
The effect of Spartina alterniflora detritus on metabolism of a muddy intertidal sediment was studied after burial of plant litter in the sediment. Total carbon dioxide release to overlying water during 3 mo following detritus enrichment increased 5.9 times while oxygen uptake only increased 1.4 times. The ratio between carbon dioxide release and oxygen uptake varied between 1 and 5 and was generally 1.6 to 3 times higher in the enriched area than in the control area. Decomposition of Spartina added to the sediment was rapid: about $50 \%$ of the mass was lost during an initial leaching phase. Loss of ash-free dry weight from the particulate matter after the leaching period was exponential with a halflife of $44.6 \mathrm{~d}$ and a decay coefficient of 0.016. Carbon dioxide released to overlying water after $105 \mathrm{~d}$ amounted to $67 \%$ of the carbon lost from the detritus. The release of DOC to overlying water accounted for only $2.8 \%$ of the particulate carbon loss. Aerobic respiration estimated from oxygen uptake corrected for chemical oxidation accounted for $21 \%$ of the total carbon dioxide production. Thus, $79 \%$ of the carbon dioxide originating from the Spartina during detritus decomposition over 3 mo was produced by anaerobic metabolism. The importance of anaerobic decomposition after enrichment of the sediment with detritus was apparent in the development of a low Eh in the detritus layer.
\end{abstract}

\section{INTRODUCTION}

Recent studies in the Bay of Fundy (Nova Scotia) have shown that Spartina alterniflora Loisel growing on intertidal flats is an important primary producer in the upper parts of the bay. Hargrave et al. (1983) found a maximum above-ground live biomass of $389 \mathrm{~g}$ DW $\mathrm{m}^{-2}$ for Spartina at the site of the present study. Prouse et al. (MS) reported an annual above-ground primary production for lower salt marshes dominated by Spartina alterniflora of $215 \mathrm{~g} \mathrm{C} \mathrm{m}^{-2} \mathrm{yr}^{-1}$. This source of material constituted up to $32 \%$ of the total primary production estimated for one of the upper basins of Bay of Fundy. Studies of stable carbon isotope ratios in the Bay of Fundy also have indicated that Spartina may be an important carbon source for higher trophic levels (Schwinghamer et al., 1983).

However, only few herbivores graze directly upon marsh grasses (Mann, 1972; Patriquin, 1981) and most of their biomass is transformed to detritus which may

\footnotetext{
- Present address: Institute of Biology, Odense University, Campusvej 55, DK-5230 Odense M, Denmark
}

be utilized by detritivores. The detritus originating from Spartina may be buried in the sediment at the location of growth or may be transported from salt marshes by tidal currents and deposited elsewhere. Thus, observations from the Bay of Fundy (Roberts, 1982; Hargrave et al., 1983; Schwinghamer et al., 1983) show that Spartina debris is widely distributed and also found buried in sediments outside the salt marshes.

The fate of Spartina litter and marine vascular macrophytes in general that becomes buried in the sediment is poorly known. Hackney and de la Cruz (1980) studied the decomposition of roots and rhizomes of the marsh plants Spartina cynosuroides and Juncus roemerianus in the sediment using litter bags; they found relatively low decomposition rates and decreasing rates with sediment depth due to anoxic conditions. However, Jørgensen and Fenchel (1974) reported high decomposition rates with more than $50 \%$ of the total mineralization of organic material due to anaerobic sulfate reduction in an aquaria system where Zostera marina was buried in the sediment. Similar figures for the importance of the sulfate reduc- 
tion were found in a coastal marine sediment (Jørgensen, 1977). Howarth and Teal (1979) also observed high rates of sulfate reduction and found that it was the most important pathway for decomposition of organic matter in a Massachusetts salt marsh.

An alternative method for assessing the relative importance of anaerobic decomposition in the metabolism of benthic systems is to measure the ratio between carbon dioxide release and oxygen uptake. The basis for this approach is that oxygen uptake in the dark, corrected for chemical oxygen uptake, represents aerobic respiration, whereas release of carbon dioxide in the dark is an integrated measure of aerobic respiration, nitrate and sulfate respiration and methanogenesis. If carbonate precipitation and chemoautotrophic production also occur, carbon dioxide is retained within the sediment and not released to overlying water. Methanogenesis may also consume carbon dioxide under certain circumstances (Fenchel and Blackburn, 1979). The method of simultaneous measurement of oxygen and carbon dioxide flux to follow benthic metabolic activity has the advantage that both aerobic and anaerobic heterotrophic processes may be quantified in an undisturbed sedimentary system. Rich (1979) used the approach to investigate benthic community metabolism in a soft-water lake and Hargrave and Phillips (1981) studied the seasonal variation of the ratio of oxygen and carbon dioxide flux between a marine subtidal sediment and overlying water by measurements with benthic chambers. Hanson and Tenore (1981) have estimated the relative importance of aerobic and anaerobic metabolism for decomposing detritus in a laboratory microcosm.

Non-living material of Spartina was experimentally buried in an intertidal sediment in the present study. This represents a new approach for studying the decomposition of vascular plants in sediments under field conditions without enclosing the plant material in litter bags or similar enclosures that may disturb sediment-detritus-organism interactions. The purpose of the present study was to assess the influence of Spartina enrichment in the sediment on rates of aerobic and anaerobic decomposition by comparing oxygen uptake and carbon dioxide release. We also constructed a carbon budget for the decomposing Spartina detritus by calculating the loss of particulate carbon, release of dissolved organic carbon and fluxes of carbon dioxide and oxygen across the sediment-water interface.

\section{MATERIALS AND METHODS}

The study was carried out in an intertidal area located at Anthony Park on the southern shore of Cobequid Bay in the upper end of Bay of Fundy, Nova
Scotia. Cobequid Bay has a large tide with a mean range of $11.7 \mathrm{~m}$ near Anthony Park (Dalrymple et al., 1975). The experimental site was flooded about $4 \mathrm{~h}$ during each tidal cycle. For a further description of the study area see Hargrave (1978) and Hargrave et al. (1983). The experimental site in this study corresponds to Station 2 described in Hargrave (1978).

Above-ground living biomass of Spartina alterniflora was harvested on July 28, 1982 and gently rinsed with cold tap water. The plant material was cut into $1.5 \mathrm{~cm}$ pieces and dried at $60^{\circ} \mathrm{C}$ for $1 \mathrm{~d}$, and $400 \mathrm{~g} \mathrm{~m}^{-2}$ was buried on August 9, 1982, in the intertidal mudflat sediment just outside the lower edge of the Spartina zone. The upper $1.5 \mathrm{~cm}$ sediment was scraped away from a $1.5 \mathrm{~m}^{2}$ area after which the Spartina material was uniformly distributed in the plot $(+\mathrm{Sp})$, and finally the sediment was replaced. Another $1.5 \mathrm{~m}^{2}$ area acting as a control $(-\mathrm{Sp})$ was treated in a similar way except that no Spartina was buried.

Plexiglass cores of undisturbed sediment with a diameter of $5.7 \mathrm{~cm}$ and a length of $11.5 \mathrm{~cm}$ were collected at intervals and brought to the laboratory $(1 \mathrm{~h}$ transport time). Measurements of fluxes across the sediment surface were carried out in the laboratory after carefully siphoning filtered (Whatman GF/C) sea water to fill the core tube $(60$ to $110 \mathrm{ml}$ ) above the sediment surface. Usually 6 cores were taken from each area, 3 of them were poisoned with $1 \%$ buffered $(\mathrm{pH} 7.2)$ formalin to act as abiotic controls. Filtered sea water containing formalin was prepared at least $24 \mathrm{~h}$ before use. Freshly mixed solution of formalin can consume oxygen (Pamatmat, 1977) but mixtures held for more than 24 h have an insignificant oxygen uptake when incubated as controls to correct for changes in oxygen without sediment present. All cores were closed with a plexiglass lid and sealed with silicon grease. A rotating magnetic bar attached to the underside of each lid mixed the water during incubation in a controlled temperature incubation.

Oxygen uptake was determined by measuring oxygen concentration in the water above the sediment in the cores at the beginning and end of a dark incubation period. Oxygen concentration was measured by oxygen electrodes with a precision of $0.1 \mathrm{mg} \mathrm{O}_{2} \mathrm{l}^{-1}$ (Radiometer Blood Gas Analyser or Yellow Spring Instrument Model 54A). The incubations were carried out at temperatures close to those in the field at the time of collection. Incubation time varied between 30 min and $5 \mathrm{~h}$ depending on temperature and rates of gas flux.

Release of carbon dioxide was measured simultaneously with oxygen uptake. Total carbon dioxide concentration was determined with a gas chromatograph (Fisher Gas Partitioner) after gas-stripping of a $20 \mathrm{ml}$ sample in a $50 \mathrm{ml}$ glass syringe (Stainton, 1973). Oxy- 
gen uptake and carbon dioxide release due to biological processes were calculated as the rates in unpoisoned cores minus the rates in formalin poisoned cores. Poisoning with formalin interferes with several processes involved in oxygen and carbon dioxide production and consumption (Dale, 1978). Biotic sulfur oxidation is stopped, hence production of reduced sulfides and their oxidation is reduced. Also, if chemoautotrophic fixation of carbon dioxide is significant, poisoning will stop this uptake. The net effect could be that total heterotrophic activity is underestimated to the extent that processes of chemoautotrophic carbon dioxide fixation and sulfur oxidation are important in the sediment. Rates of gas exchange calculated as the difference in poisoned and unpoisoned cores may therefore underestimate total heterotrophic activity while aerobic metabolism is overestimated.

Sediment temperature was determined when cores were collected with a shaded thermometer (precision $0.1 \mathrm{C}^{\circ}$ ) inserted to $1 \mathrm{~cm}$ depth between $10 \mathrm{a} . \mathrm{m}$. and 1 p.m. when the midflat was emerged. Temperature of water, sediment and air measured simultaneously showed that the sediment generally was warmer than water during low tide. This effect was most pronounced during spring when the water was cold while air temperature increased. There were usually only minor differences from August through fall, and on occasion the sediment can be colder than the water (D. C. Gordon, Jr., unpubl.). We assume that the flux rates measured at field temperatures are equivalent to or slightly above the average for the day due to this temperature effect.

Rates of oxygen and carbon dioxide flux were considered representative for both ebb and flood conditions because measurements of water content in a similar sediment were equal before and after flooding (D. C. Gordon, Jr., unpubl.). Furthermore, Teal and Kanwisher (1961) found no significant differences in oxygen uptake by cores from a Georgia marsh whether measured in air or in water.

Samples of overlying water were taken from the unpoisoned cores before and after all incubations for measurements of dissolved organic carbon (DOC). The samples were stored in glass tubes (combusted at $550^{\circ} \mathrm{C}$ ) with acid-washed-teflon-lined caps at $-20^{\circ} \mathrm{C}$ until analysis. Analysis of DOC was made by IR-detection after UV-oxidation (Gershey et al., 1979).

The sediment in cores from $(+\mathrm{Sp})$ was sieved through a $1 \mathrm{~mm}$ sieve after the flux measurements and recognizable Spartina fragments above this size were recovered. The plant material was gently rinsed in deionized water, dried at $60^{\circ} \mathrm{C}$ for $1 \mathrm{~d}$ and weighed (DW). Subsamples were treated in a muffle furnace at $550^{\circ} \mathrm{C}$ for $1 \mathrm{~d}$ before determination of ash free dry weight (AFDW). Organic carbon and nitrogen were determined on acidified ( $1 \mathrm{~N} \mathrm{HCl}$ ) subsamples with a Perkin-Elmer 240 Elemental CHN Analyser.

A leaching experiment with a subsample of Spartina material added to the plot was conducted in the laboratory at $20^{\circ} \mathrm{C}$. Cut pieces of Spartina $(6 \mathrm{~g} \mathrm{DW})$ were put into 1.51 filtered $(0.45 \mu \mathrm{m})$ sea water from Bay of Fundy in a conical flask. Mercuric chloride $0.1 \%$ final conc.) was added to the water to prevent bacterial growth. The suspension was stirred by a rotating magnetic bar. Water samples were taken at intervals and filtered through glassfiber filters (combusted at $550^{\circ} \mathrm{C}$ ) for DOC analysis. The suspension was filtered through a $1 \mathrm{~mm}$ net after $6 \mathrm{~d}$ and the filtrate again filtered through a preweighed glassfiber filter. All the plant fragments collected on the mesh and the filters were dried at $60^{\circ} \mathrm{C}$ for dry weight determination.

Redox potential was recorded on sediment cores from the experimental plots, from an undisturbed mudflat and from a Spartina stand. Measurements of redox potential and calculation of Eh were made similarly to Hargrave (1972).

\section{RESULTS}

Sediment temperatures decreased slowly from August until late September (mean temp. about $20^{\circ} \mathrm{C}$ ) after which it decreased more rapidly (Fig. $1 \mathrm{~A}$ ). The first ice on the intertidal flat in 1982 was observed on December 14 . Both the biological oxygen uptake and carbon dioxide release increased in the $(+\mathrm{Sp})$ area during the first $2 \mathrm{wk}$ after the burial of Spartina material (Fig. 1 B, C). However, carbon dioxide release rates increased much more rapidly over initial values than did oxygen uptake (5.9 and 1.4 times, respectively). Maximum rates of oxygen uptake and carbon dioxide release were $2.1 \mathrm{mmol} \mathrm{m}^{-2} \mathrm{~h}^{-1}$ and $10.7 \mathrm{mmol}$ $\mathrm{m}^{-2} \mathrm{~h}^{-1}$. The rates decreased during OctoberNovember when temperatures fell abruptly. Oxygen uptake in the $(-\mathrm{Sp})$ area generally decreased throughout the experiment except for the high rate $(1.7 \mathrm{mmol}$ $\mathrm{m}^{-2} \mathrm{~h}^{-1}$ ) measured on September 16. Carbon dioxide release in the $(-\mathrm{Sp})$ area changed in an opposite manner, increasing during the first month (maximum rate $2.7 \mathrm{mmol} \mathrm{m}^{-2} \mathrm{~h}^{-1}$ ) and decreasing after mid September.

Comparisons by the Mann-Whitney U-test (Elliot, 1971) showed that mean levels of both carbon dioxide release and oxygen uptake in the $(+\mathrm{Sp})$ and the $(-\mathrm{Sp})$ areas were significantly different $(P<0.05)$. A comparison between the flux rates and sediment temperature in the field only gave significant correlations between oxygen uptake rates and temperature in $(+\mathrm{Sp})$ and $(-\mathrm{Sp})$ but not for carbon dioxide release 
Fig. 1. Variation of (A) temperature, (B) oxygen uptake, (C) carbon dioxide release, (D) ratio carbon dioxide release: oxygen uptake. Mean values \pm 1 SE in (+Sp) area (open circles); in $(-\mathrm{Sp})$ area (closed circles)
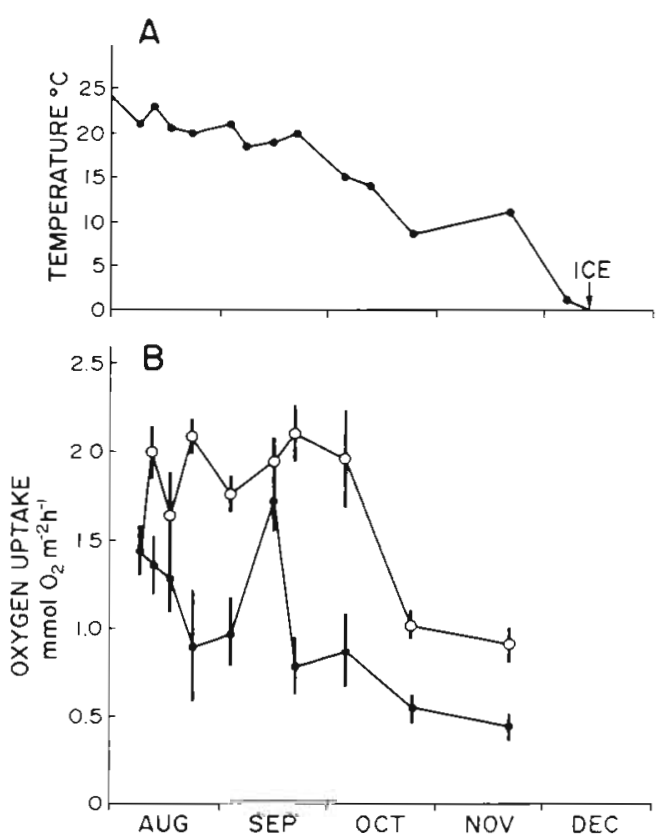
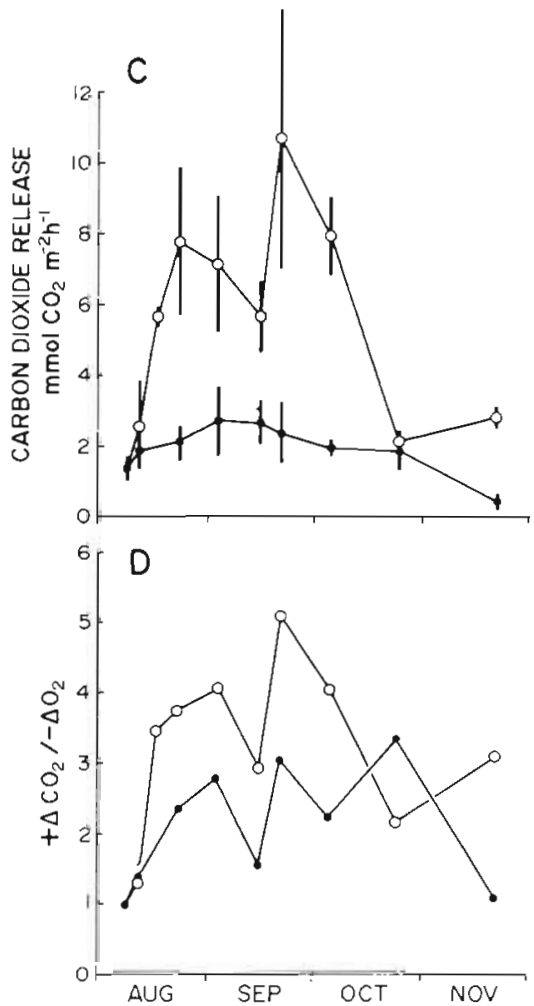

rates and temperature (Table 1). Oxygen uptake and carbon dioxide release rates were only significantly correlated $(\mathrm{P}<0.01)$ when calculated as the difference $(+\mathrm{Sp})-(-\mathrm{Sp})($ Table 1$)$.

Table 1. Correlation coefficients $\left(\mathrm{r}^{2}\right)$ between benthic oxygen uptake, carbon dioxide release and sediment temperature for $(+\mathrm{Sp})$ and $(-\mathrm{Sp})$ areas and for calculated differences $(+\mathrm{Sp})$ minus $(-\mathrm{Sp})$ for measurements $(\mathrm{n}=9)$ at Anthony Park, Cobequid Bay, Bay of Fundy

\begin{tabular}{|llll|}
\hline \multicolumn{1}{|c}{ Correlation } & $(+\mathrm{Sp})$ & $(-\mathrm{Sp})$ & $\begin{array}{c}(+\mathrm{Sp}) \\
-(-\mathrm{Sp})\end{array}$ \\
\hline $\mathrm{O}_{2}$ uptake - temperature & $0.683^{++}$ & $0.608^{+}$ & $0.027^{\circ}$ \\
$\mathrm{CO}_{2}$ release - temperature & $0.244^{\circ}$ & $0.318^{\circ}$ & $0.168^{\circ}$ \\
$\mathrm{O}_{2}$ uptake $-\mathrm{CO}_{2}$ release & $0.483^{\circ}$ & $0.373^{\circ}$ & $0.743^{++}$ \\
& & & \\
++ Significant correlations at $\mathrm{P}<0.01$ & & \\
$+\quad$ Significant correlations at $\mathrm{P}<0.05$ & & \\
$+\quad$ Not significant & & \\
\hline
\end{tabular}

The ratio between carbon dioxide released and oxygen uptake increased from values of 1 in both plots during the first month (Fig. 1 D). Maximum ratios were 5.1 and 3.3 for the $(+\mathrm{Sp})$ and $(-\mathrm{Sp})$ areas respectively. The $(+\mathrm{Sp})$ area in general had ratios 1.6 to 3 times higher than the $(-\mathrm{Sp})$ area. In late November the ratio for the $(-\mathrm{Sp})$ decreased to 1 . Ratios in the $(+\mathrm{Sp})$ area were also lower in late October and November.

Incubation of cores at 2 temperatures (October 25-26 and November 22-24) showed similar results. $Q_{10}$ values were generally higher for carbon dioxide release than for oxygen uptake with higher values found in $(+\mathrm{Sp})$ than in $(-\mathrm{Sp})$ (Table 2). $\mathrm{Q}_{10}$ values were lower

Table 2. Average flux rates $\left(\mathrm{mmol} \mathrm{m} \mathrm{m}^{-2} \mathrm{~h}^{-1}\right)$ for carbon dioxide and oxygen across sediment/water interface at 7.5 and $17.5^{\circ} \mathrm{C}$, November $22-24 . \mathrm{Q}_{10}$ values and ratios between carbon dioxide release and oxygen uptake calculated on the basis of mean values. Numbers in parentheses: $1 \mathrm{SE}$ of adjacent mean values. $\mathrm{n}=3$

\begin{tabular}{|clllll|}
\hline Rate & & $7.5^{\circ} \mathrm{C}$ & $17.5^{\circ} \mathrm{C}$ & $\mathrm{Q}_{10}$ \\
\hline $\mathrm{CO}_{2}$ release & $(+\mathrm{Sp})$ & $1.54(0.30)$ & $7.63(0.53)$ & 4.95 \\
& $(-\mathrm{Sp})$ & $0.28(0.18)$ & $1.16(0.44)$ & 4.14 \\
$\mathrm{O}_{2}$ uptake & $(+\mathrm{Sp})$ & $0.55(0.10)$ & $2.19(0.29)$ & 3.97 \\
& $(-\mathrm{Sp})$ & $0.30(0.06)$ & $0.75(0.10)$ & 2.46 \\
$+\mathrm{CO}_{2}:-\mathrm{O}_{2}$ & $(+\mathrm{Sp})$ & 2.80 & 3.48 & \\
& $(-\mathrm{Sp})$ & 0.93 & 1.54 & \\
& & & &
\end{tabular}

and the ratio carbon dioxide release: oxygen uptake were higher in October than in November. The ratio between carbon dioxide release and oxygen uptake 
increased with temperature in both control and enriched plots.

Oxygen uptake and carbon dioxide release rates discussed above were calculated as the difference in flux between unpoisoned and formalin-poisoned cores. The oxygen uptake and the carbon dioxide release in poisoned cores was on average 17.8 (S.D. \pm 4.3 ) and 33.4 (S.D. \pm 15.6 ) \% of exchange rates in unpoisoned cores, respectively. There was no obvious patterns of fluxes in poisoned cores.

Redox potential measurements in the $(+\mathrm{Sp})$ area on September 19 (Day 37), when compared to the ( $-\mathrm{Sp}$ ). area showed significantly lower values at the depth $(1.5 \mathrm{~cm})$ where Spartina was buried (Fig. $2 \mathrm{~A}, \mathrm{~B}$ ). Minimum values were similar to those measured in a natural Spartina stand (Fig. 2 B). Redox potentials in the $(-\mathrm{Sp})$ area were uniform with depth below the

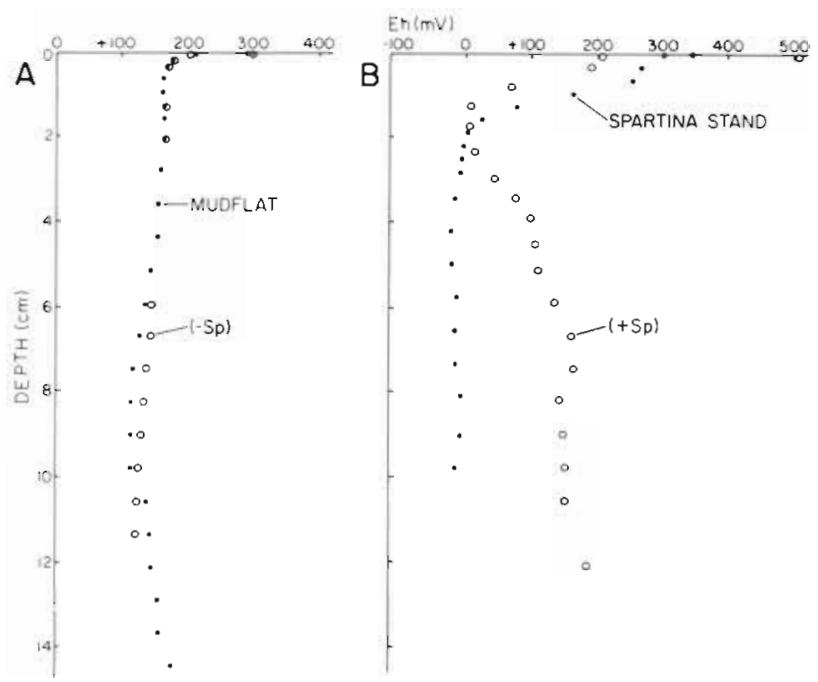

Fig. 2. Redox potentials in sediment cores from Anthony Park, September 15, 1982. (A) Undisturbed mudflat (closed circles) and (-Sp) area (open circles). (B) Spartina stand (closed circles) and $(+\mathrm{Sp})$ area (open circles)

redoxcline found in the upper $0.5 \mathrm{~cm}$ and corresponded to the undisturbed mudflat (Fig. 2 A). Potentials in sediment from the mudflat were 150 to $200 \mathrm{mV}$ higher than values at all depths below the surface to $-12 \mathrm{~cm}$ in the Spartina stand.

Total carbon dioxide production and aerobic respiration due to decomposition of Spartina added to the sediment (Fig. 3) were calculated as the difference in oxygen uptake and carbon dioxide release between the $(+\mathrm{Sp})$ and $(-\mathrm{Sp})$ areas (Fig. $1 \mathrm{~B}, \mathrm{C}$ ). The assumption for this calculation is that the buried Spartina is the only difference between the 2 areas. No visual difference in macrofauna biomass or species composition existed between the 2 areas, although this was not systematically investigated. Cumulative oxygen
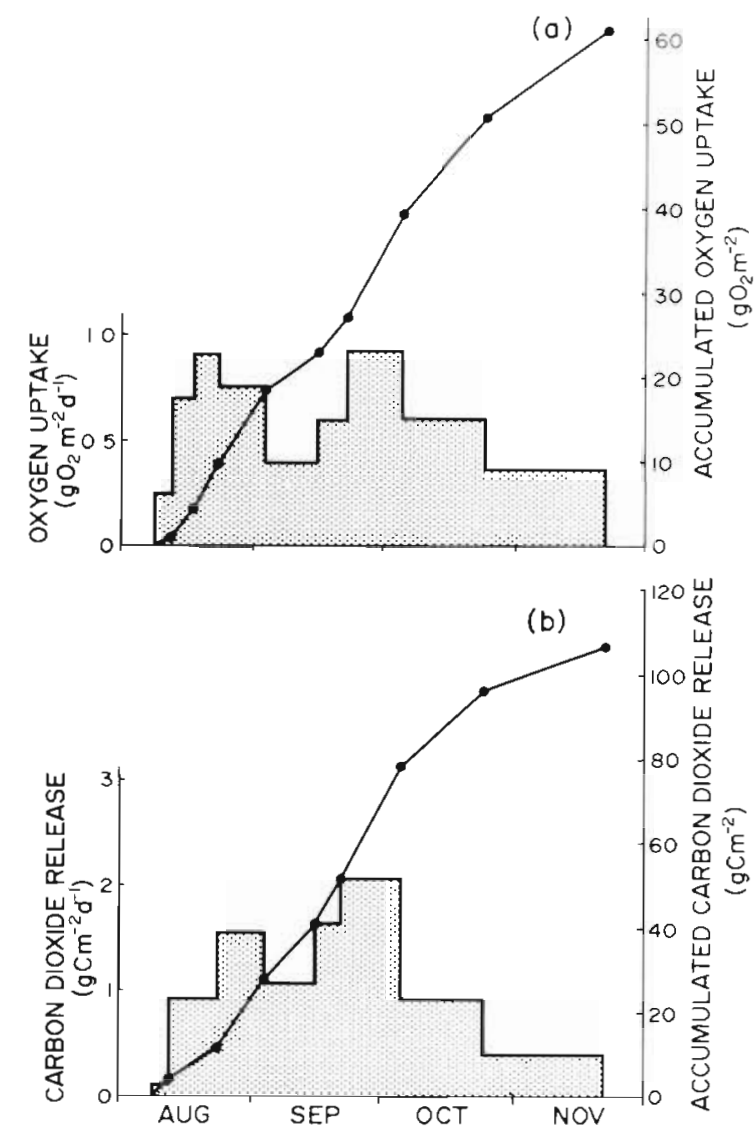

Fig. 3. Oxygen uptake and carbon dioxide release due to enrichment of Spartina material. Rates calculated as (+Sp) values minus $(-\mathrm{Sp})$ values. Cumulative figures for oxygen uptake (a) and for carbon dioxide release (b)

uptake and carbon dioxide release were estimated on the basis of these rates for the decomposition period (Fig. 3). Both curves have a sigmoid form which reflects lower rates during August and November. Cumulative carbon respiration was compared to the cumulative loss of organic carbon from the buried Spartina $>1 \mathrm{~mm}$ in size (Fig. 4). Oxygen uptake values were converted to carbon respired assuming an $R Q$ value of 1 . The ratios increased linearly during the first $70 \mathrm{~d}$, showing that increasing amounts of particulate carbon (> $1 \mathrm{~mm}$ in size) were lost through aerobic and anaerobic processes. The ratios for loss through carbon dioxide and aerobic respiration became constant after $80 \mathrm{~d}$ at levels of 0.80 and 0.17 , respectively. This indicates that at least $20 \%$ of the particulate organic carbon lost is not metabolized to carbon dioxide. The amount could be greater if carbon dioxide released by aerobic and anaerobic metabolism were fixed by chemoautotrophs.

Part of the carbon not lost as carbon dioxide is lost as DOC. Release rates were in general higher in $(+\mathrm{Sp})$ than in $(-\mathrm{Sp})$ throughout the period of observation 


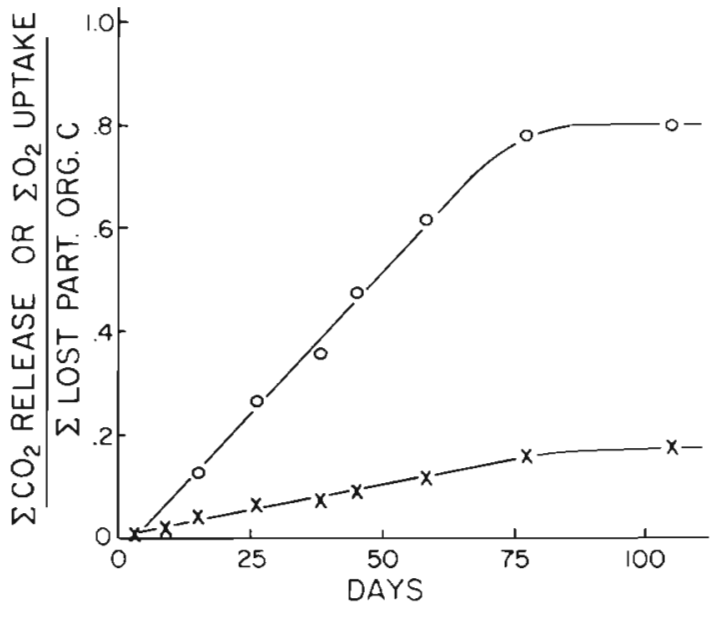

Fig. 4. Ratios between accumulated oxygen uptake and carbon dioxide release (Curves a and b, Fig. 3) and accumulated loss of carbon from particulate Spartina detritus (derived from Fig. 6)

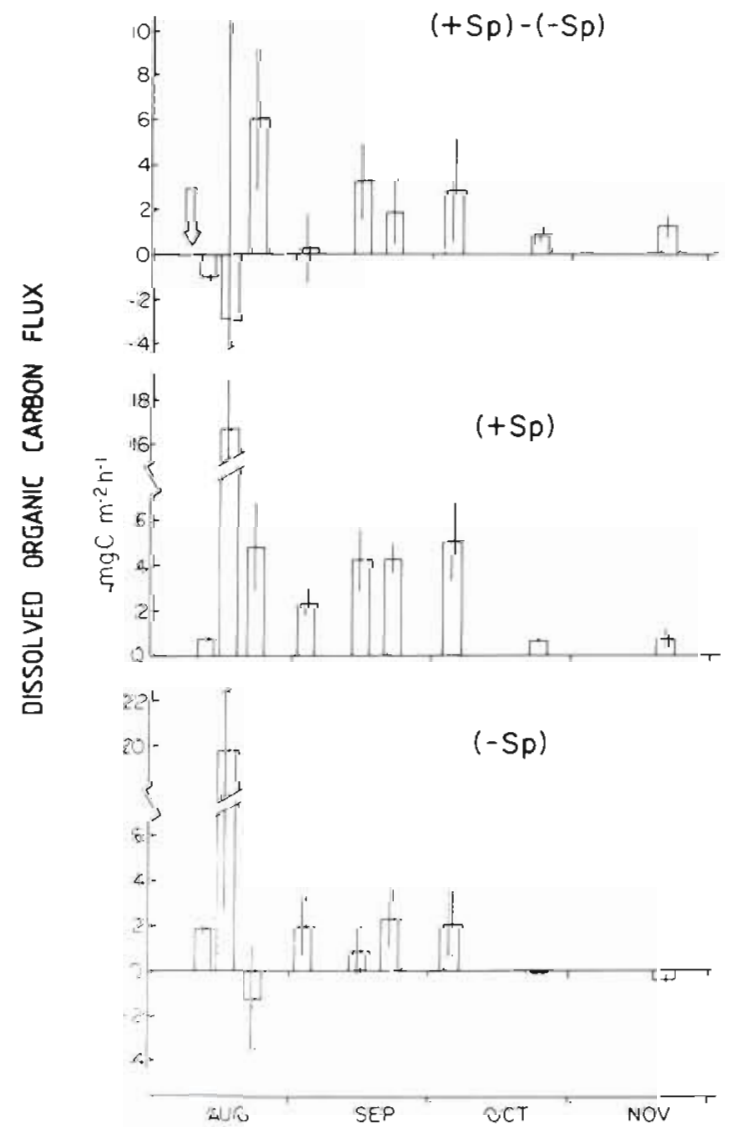

Fig. 5. Flux rates of DOC in $(+S p)$ and $(-S p)$ areas and the calculated difference $(+\mathrm{Sp})$ minus $(-\mathrm{Sp})$. Columns: mean values; vertical lines: $\pm 1 \mathrm{SE}$. Values above the line indicate DOC release; values below, DOC uptake. Arrow: date for burial of Spartina material
(Fig. 5). However, both $(-\mathrm{Sp})$ and $(+\mathrm{Sp})$ areas showed very high DOC release rates $9 \mathrm{~d}$ after the sediment had been disturbed during burial. As for measures of carbon dioxide and oxygen, release of DOC assumed to originate from buried Spartina was calculated as the difference between the 2 areas. There was a net uptake of DOC on the 2 first sampling dates, a maximum release rate of $6 \mathrm{mg}$ DOC m $\mathrm{m}^{-2} \mathrm{~h}^{-1}$ in late August after which the rates showed a variable and generally decreasing trend (Fig. 5).

The AFDW of the particulate Spartina material (>1 $1 \mathrm{~mm}$ ) sieved from cores during the experiment (Fig. 6) shows that an initial loss of weight of plant

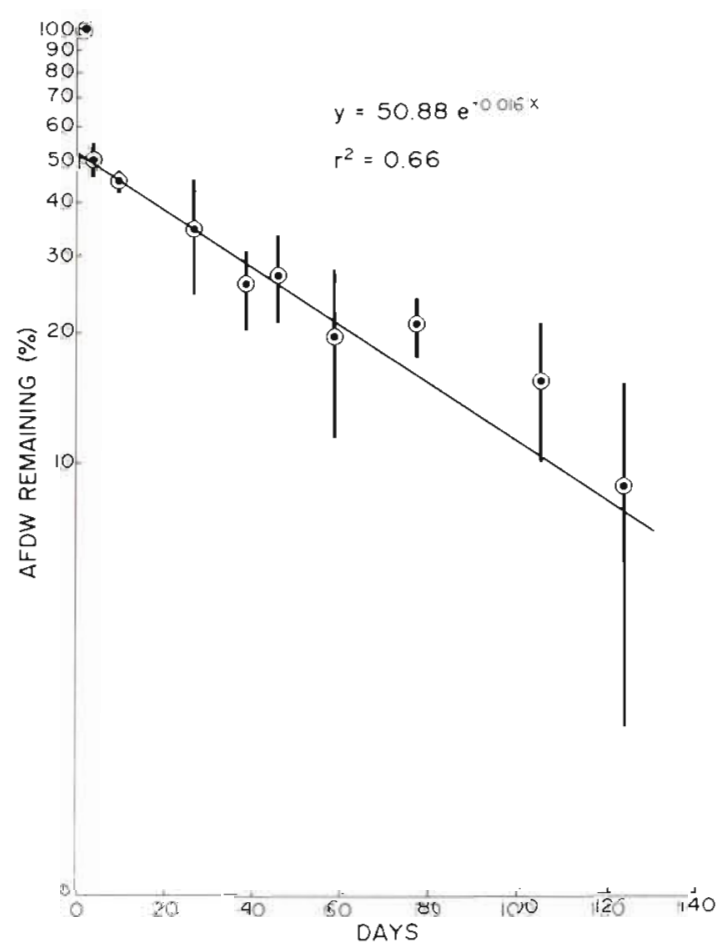

Fig. 6. Decomposition of Spartina added to sediment. Mean values of AFDW $\pm 1 \mathrm{SD}$ remaining over time. Regression line calculated using data from Day 3 to 124 , excluding initial leaching phase

fragments of about $50 \%$ occurred during the first $4 \mathrm{~d}$. The data for the remaining period were fitted to an exponential curve $\left(r^{2}=0.66\right)$. The decay coefficient was 0.016 which gives a half-life for the particulate matter of $44.6 \mathrm{~d}$. Only $8.6 \%$ of the AFDW of Spartina material remained in fragments $>1 \mathrm{~mm}$ after $124 \mathrm{~d}$. Leaching in the laboratory showed a loss over $6 \mathrm{~d}$ of $185 \mathrm{mg} \mathrm{g}^{-1} \mathrm{DW}$ from Spartina pieces identical to those used in the field experiment. Of this loss $7.2 \%$ was as fine particles trapped on a glass fiber filter after passing a $1 \mathrm{~mm}$ net and $32.9 \%$ was DOC. Assuming a carbon content of $40 \%$ in dissolved organic matter, 
this would constitute $88.5 \%$ of the total dissolved matter lost.

Both the carbon and nitrogen content in the decomposing litter increased during the first month from 43 to 50 and from 1.8 to $2.6 \%$ of AFDW, respectively; thereafter values became almost constant. The $\mathrm{C} / \mathrm{N}$ ratio in the plant material buried in the sediment was 23.9 and the mean of measurements after the leaching period was 20.5 (S.D. \pm 2.5 ).

A budget for organic carbon loss from the buried Spartina material was calculated from measurements of particulate carbon remaining over time, loss of DOC, loss of carbon dioxide and aerobic respiration estimated from oxygen uptake (Fig. 7). After $105 \mathrm{~d}$ of

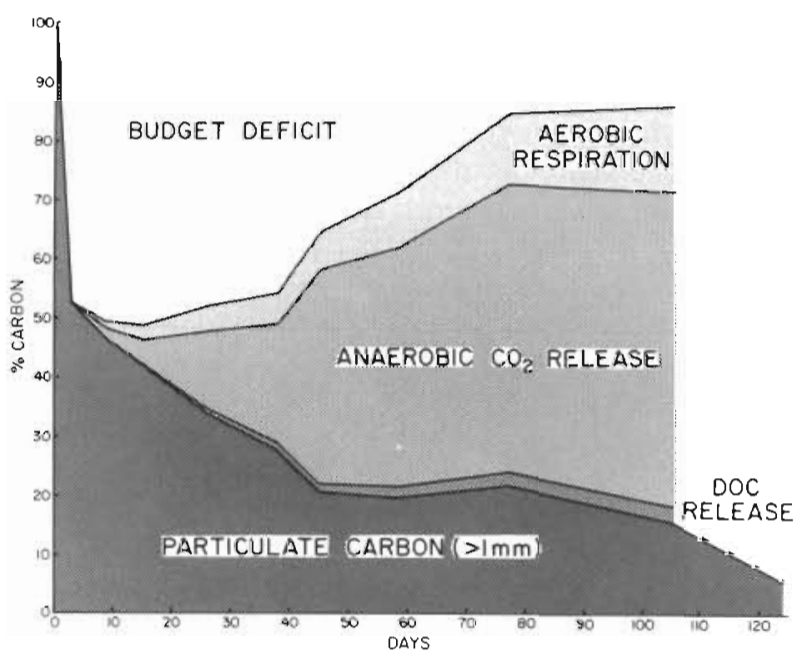

Fig. 7. Carbon budget for decomposition of Spartina detritus added to sediment. Particulate carbon (as recognizable pieces of Spartina $>1 \mathrm{~mm}$ ) remaining in the sediment, DOC released, anaerobic carbon dioxide released, aerobic respiration, and carbon deficit calculated by difference from the initial amount of carbon added to the sediment on basis of mean values derived from individual sampling dates (Fig. 3, 5 and 6). Cumulative values for DOC, anaerobic carbon dioxide and oxygen flux were too small to be plotted on Day 3

decomposition $84.4 \%$ of the original amount of particulate carbon (>1 mm) had been lost. Of this $67.3 \%$ had been metabolized to carbon dioxide, $2.8 \%$ was lost as DOC and $14.3 \%$ was lost in other ways (e.g. by resuspension, $\mathrm{CH}_{4}$ and as fine particulate matter $<1 \mathrm{~mm}$ ). A greater fraction would have been lost if carbon dioxide release had been underestimated due to chemoautotrophic fixation. The deficit fraction in the budget was especially high in the beginning and gradually decreased during the decomposition. If chemoautotrophic fixation of carbon dioxide was most rapid during early stages of decomposition, low rates of carbon dioxide production observed early in the experiment (Fig. 1) might have actually been higher.
Aerobic respiration accounted for $21.3 \%$ of the total carbon dioxide release, assuming an RQ value of 1 .

\section{DISCUSSION}

Oxygen uptake rates for the unenriched area $(-\mathrm{Sp})$ may be compared to rates measured in previous studies of benthic metabolism of mudflats in the Bay of Fundy. Hargrave et al. (1983) observed lower rates of oxygen uptake (about $0.6 \mathrm{mmol} \mathrm{m} \mathrm{m}^{-2} \mathrm{~h}^{-1}$ for August) at the same intertidal site whereas rates between 0.9 and $1.4 \mathrm{mmol} \mathrm{m} \mathrm{m}^{-2} \mathrm{~h}^{-1}$ were found in this study. The difference may be due to the stirring during incubation of cores in the present study since water over sediment was unstirred in the previous study. Increased oxygen uptake as a result of water circulation has been observed in other studies (Boynton et al., 1981). This effect makes the direct comparison of rates derived in different studies difficult but it does not prevent comparison of rates obtained in one study where a standard method of circulation has been used.

Oxygen and carbon dioxide exchange in sediments from the $(+\mathrm{Sp})$ area may be more directly compared with rates observed in natural salt marsh sediments because of the higher organic content in the experimental plot enriched with Spartina. Smith and Teal (cited in Howarth and Teal, 1979) found rates of total sediment oxygen uptake uncorrected for chemical oxygen uptake of $1.3 \mathrm{mmol} \mathrm{m} \mathrm{m}^{-2} \mathrm{~h}^{-1}$ in August at Great Sippewissett Marsh. The mean rate for oxygen uptake from mid-August to mid-October was about $1.9 \mathrm{mmol}$ $\mathrm{m}^{-2} \mathrm{~h}^{-1}$ in our study. Thus, addition of Spartina to the sediment increased oxygen uptake to a level above that observed in a natural salt marsh. Higher oxygen uptake has also been reported from other salt marshes. Total oxygen uptake in Georgia marshes during summer is about $2.3 \mathrm{mmol} \mathrm{m} \mathrm{m}^{-2} \mathrm{~h}^{-1}$ (Teal and Kanwisher, 1961) and in a Louisiana marsh about 2.4 to 5.0 (Day et al., 1973). Duff and Teal (1975) report even higher oxygen uptake rates for a low salt marsh at Kingsport, Bay of Fundy; however, their measurements were made with a different method. Howarth and Hobbie (1982) provide a summary of these observations in marsh areas.

Carbon dioxide release rates for the unenriched (-Sp) area from August to November $(2.2 \mathrm{mmol}$ $\mathrm{m}^{-2} \mathrm{~h}^{-1}$ ) were similar to those found by Teal and Kanwisher (1961), Pamatmat (1968), Granéli (1979) and Hargrave and Phillips (1981). In general, the ratio between carbon dioxide release and oxygen uptake was greater than unity (between 1 and 5) (Fig. $1 \mathrm{D}$ ). Hargrave and Phillips (1981) found ratios between 1.8 and 4 for a sandy subtidal marine sediment and Rich (1979) reported ratios from 0.8 to 9 for a number of 
lakes. The higher ratios illustrate the importance of anaerobic metabolism in these sediments. Anaerobic processes are enhanced by the addition of organic matter since carbon dioxide release was increased 5.9 times above that measured at the beginning of the experiment, whereas oxygen uptake only increased 1.4 times. The development of low redox potentials $(0 \mathrm{mV}$, Fig. 2 B) at the depth of Spartina burial also shows the predominance of anaerobic decomposition processes created by the organic enrichment. Howarth and Teal (1979) concluded that anaerobic decomposition in a salt marsh sediment is limited by the availability of energy (substrate) and not by nutrients since enrichment with a commercial fertilizer did not increase rates of sulfate reduction.

Teal and Kanwisher (1961), Pamatmat (1968) and Granéli (1979) found ratios of carbon dioxide release to oxygen consumed of $\leq 1$ in a variety of marine and freshwater sediments. As mentioned above, microbial processes such as chemoautotrophy, heterotrophy and methanogenic refixation of carbon dioxide in the sediment may have contributed to these low ratios, although the extent to which these processes are developed in any particular benthic environment is variable (Wolfe, 1971; Sorokin, 1972; Kepkay and Novitsky, 1980). Howarth and Teal (1979), referring to an earlier study by Teal and Kanwisher (1961), also suggested that carbon dioxide may be taken up by plant roots or may have been transported laterally in the pore water, although these vectors for loss were not present in our experiments.

The ratio between carbon dioxide release and oxygen uptake in our study was calculated on the basis of the formalin sensitive flux rates (i.e. the portion of total exchange due to biological processes). Oxygen uptake in the poisoned cores is presumably caused by reduced substances, e.g. $\mathrm{H}_{2} \mathrm{~S}$ diffusing to the sediment-water interface; however, formalin poisoning may also decrease oxidation of reduced sulfur compound, since oxidation by chemoautotrophs may be greater than chemical oxidation (Dale, 1978; Jørgensen, 1982). Carbon dioxide release presumably occurs by diffusion from the large pool of total carbon dioxide in pore water (Kepkay et al., 1981). Differences in pool sizes and diffusion rates may be the reason for the observed average reduction in flux rates for oxygen $(82.2 \%)$ and carbon dioxide $(66.6 \%)$ due to poisoning. When formalin is added to the water in a core, it probably immediately stops metabolism by both aerobic and anaerobic bacteria near the sediment-water interface. Burrowing macrofauna also appears to die quickly after formalin addition. However, it takes a longer time for anaerobic bacteria deeper in the sediment to be poisoned. Dale (1978) also pointed out that during this delay in poisoning in short-term experiments, anaerobic bacteria may continue to produce carbon dioxide which may be released into the water. The ratio between carbon dioxide release and oxygen uptake in our experiments would have been slightly higher had it been calculated on the basis of total flux rates.

Sediment-oxygen uptake in our experiments was correlated with temperature as in previous studies (Pamatmat, 1977). However, carbon dioxide release was uncorrelated with this variable (Table 1). Hargrave and Phillips (1981) found that temperature measured over an annual period accounted for a greater amount of variation in oxygen uptake than of carbon dioxide release. In contrast to these results, our laboratory experiments with incubations of the cores at different temperatures showed higher $Q_{10}$ values for carbon dioxide release than for oxygen uptake. This might indicate that anaerobic processes, which exert decisive influence on carbon dioxide release, are more sensitive to temperature changes than are processes involved in oxygen uptake. The apparent response to temperature changes in the field may be due to other factors that vary concomitantly with temperature, or to adaptation, or - in this study - also to ageing of buried Spartina detritus. These factors were eliminated in the laboratory experiment where the cores were stored overnight at the new temperature before incubation. In agreement with our laboratory experiments, Nedwell and Floodgate (1972) suggested that sulfate reduction - undoubtedly the most important anaerobic process in our sediment - is more sensitive to temperature than the overall activity of the bacterial population in the sediment. On the other hand, Jorgensen (1977) reported similar temperature coefficients for sulfate reduction and total oxygen uptake; however, $50 \%$ of the oxygen uptake in his studies were due to oxidation of sulfide originating from sulfate reduction.

The 3 vectors for loss of detrital carbon (aerobic respiration, anaerobic respiration, DOC release) did not change in a similar way during our experiments. The amount of carbon lost through aerobic respiration and carbon dioxide release per amount of carbon lost from the particulate detritus increased linearly during the first $70 \mathrm{~d}$ from 0 to 0.17 and 0.80 for oxygen and carbon dioxide, respectively (Fig. 4). This means that there was a time lag between observed loss from the particulate carbon in the sediment and the appearance of carbon as respired carbon dioxide released into the water. If all particulate carbon lost was respired to carbon dioxide within the period of the experiment with no fixation by chemoautotrophs the ratio should have reached 1 . However, a constant value of 0.80 was achieved. This shows that about $20 \%$ of the particulate carbon was not lost as carbon dioxide but in other forms (e.g. as DOC, $\mathrm{CH}_{4}$, fine-particulate organic car- 
bon with sizes $<1 \mathrm{~mm}$ ) or remained stored in the sediment as refractory organic carbon. Chemoautotrophy would result in an underestimate of the carbon dioxide produced.

Release of DOC from the sediment was in general low for both plots (Fig. 5). Pomeroy et al. (1977) also found low rates, about $6 \mathrm{mg} \mathrm{C} \mathrm{m} \mathrm{C}^{-2} \mathrm{~h}^{-1}$, in a Georgia salt marsh. Typical rates for the $(-\mathrm{Sp})$ and $(+\mathrm{Sp})$ areas were 2 and $4.5 \mathrm{mg} \mathrm{C} \mathrm{m}^{-2} \mathrm{~h}^{-1}$, respectively. The high rates obtained $9 \mathrm{~d}$ after the start of the experiment may be due to sediment disturbance during burial of the Spartina as well as to loss of water-soluble organic compounds lost during early stages of decomposition. The low rates in October and November were probably due to low temperature and ageing of the buried plant material in the $(+\mathrm{Sp})$ plot. The difference between the 2 areas (assumed to represent DOC flux created by buried Spartina) showed an initial uptake which may have been due to a stimulation of the microbial flora caused by nutrients released after disturbance of the sediment. The low release rates to overlying water also imply that most of the DOC is metabolized in the sediment.

The fast initial leaching of soluble substances observed in the laboratory was probably responsible for the rapid loss of AFDW from buried plant material (Fig. 6). However, leaching amounted to $19 \%$ of the AFDW in the laboratory, whereas about $50 \%$ of the carbon was not present in particles $>1 \mathrm{~mm}$ after a few days burial in the sediment. This may be due to faunal and microbial activity and a higher adsorption capacity in the sediment since the laboratory experiment was conducted with sea water containing mercuric chloride. Cores used for measuring particulate Spartina remaining in the sediment were taken only from areas of the test plot where the sediment surface was undisturbed in order to eliminate errors due to erosion.

Data from the period after leaching showed that AFDW was lost exponentially from the buried plant material. Decomposition rate $\left(1.55 \% \mathrm{~d}^{-1}\right)$ is similar to values reported for Spartina enclosed in litter bags in high and low marsh environments (Marinucci, 1982). However, other studies have shown considerably lower decomposition rates for Spartina and comparable emergent freshwater macrophytes placed in litter bags and crates (Burkholder and Bornside, 1957; Odum and de la Cruz, 1967; Mason and Bryant, 1975; Andersen, 1978; Howarth and Hobbie, 1982). The rapid decomposition rates also contrast values for roots and rhizomes of Spartina cynosuroides in sediment (Hackney and de la Cruz, 1980). Low rates were attributed to anoxic conditions within the rhizosphere of marsh grass. Redox measurements and the ratio between carbon dioxide release and oxygen uptake in our study show that high rates of anaerobic decomposi- tion can occur in anoxic sediment. Godshalk and Wetzel (1978) similarly found no significant difference between the decomposition of 5 freshwater macrophytes under aerobic and anaerobic conditions in a laboratory experiment.

Studies on decomposing vascular plants have generally shown a decreasing carbon:nitrogen ratio after the initial leaching period due to an increase in relative nitrogen content (Rice and Tenore, 1981). We observed an initial increase in relative amounts of both carbon and nitrogen followed by almost constant concentrations. The resulting carbon:nitrogen ratio fell rapidly during leaching and then increased slowly. This pattern is similar to that observed for most species by Godshalk and Wetzel (1978). The initial level of nitrogen in the decomposing plant litter is important for the decomposition rate (Godshalk and Wetzel, 1978). Thus, the initial nitrogen content of the Spartina material in our study ( $\mathrm{C}: \mathrm{N}=24, \mathrm{~N} \%$ of $\mathrm{DW}=1.65)$ contrasts with that of detritus decomposed in the study by Rice and Tenore (1981) ( $\mathrm{C}: \mathrm{N}=120, \mathrm{~N} \%$ of $\mathrm{DW}=0.4)$.

Most of the carbon lost from the decomposing Spartina detritus was respired as carbon dioxide" (Fig. 7). Release of DOC to the water column accounted for a small fraction of the loss. The high budget deficit during the first month of the experiment (Fig. 7) might have been due to loss not measured directly, for example erosion and decomposition to fine-particulate carbon $(<1 \mathrm{~mm})$. However, since the release of carbon dioxide into the water exceeded the loss of particulate carbon in plant material, other pools of organic carbon in the sediment must have been oxidized. These pools are probably DOC and fine particulate carbon derived from Spartina detritus. DOC may be considered the most important of these pools because the budget deficit increased during leaching and because we measured a high leaching of DOC in the laboratory under poisoned conditions. This may mean that the budget deficit represents the storage of organic carbon within the sediment which has not been oxidized to carbon dioxide for release into the overlying water.

The large fraction of carbon decomposed anaerobically (79\%) stresses the importance of anaerobic processes for carbon cycling in marine sediments. Other studies in salt-marsh sediments (Howarth and Teal, 1979; Howarth and Giblin, 1983) have indicated that sulfate reduction is quantitatively the most important process for oxidation of organic carbon, while nitrate reduction and methanogenesis are of minor importance (Kaplan et al, 1979). Anaerobic decomposition may be less important in mudflats where Spartina is not buried. However, in sediments with low redox potentials - similar to those in Spartina marsh - our figures for the relative importance of anaerobic decomposition are probably representative. 
Acknowledgements. We thank Dr. Peter Wangersky for use of the DOC analyser and Dr. D. C. Gordon Jr. for providing unpublished data. This work was supported by grant no. 113332 from the Danish Natural Science Research Council to F. Ø. Andersen.

\section{LITERATURE CITED}

Andersen, F. Ø. (1978). Effects of nutrient level on the decomposition of Phragmites communis Trin. Arch. Hydrobiol. 84: $42-54$

Boynton, W. R., Kemp, W. M., Osborne, C. G., Kaumeyer, K. R., Jenkins, M. C. (1981). Influence of water circulation rate on in situ measurements of benthic community respiration. Mar. Biol. 65: 185-190

Burkholder, P. R., Bornside, G. H. (1957). Decomposition of marsh grass by aerobic marine bacteria. Bull. Torrey Bot. Club 84: 366-383

Dale, T. (1978). Total, chemical and biological oxygen consumption of the sediments in Lindåspollene, Western Norway. Mar. Biol. 49: 333-341

Dalrymple, R. W., Knight, R. J., Middleton, G. V. (1975). Intertidal sand bars in Cobequid Bay (Bay of Fundy). In: Cronin, L. E. (ed.) Estuarine research. Academic Press, New York, p. 293-307

Day, J. W., Smith, W. G., Wagner, P. R., Stowe, W. C. (1973). Community structure and carbon budget of a salt marsh and shallow bay estuarine system in Louisiana. Center for Wetland Resources, Louisiana State University, Baton Rouge

Duff, S., Teal, J. M. (1975). Temperature change and gas exchange in Nova Scotia and Georgia salt-marsh muds. Limnol. Oceanogr. 10: 67-73

Eliiot, J. M. (1971). Some methods for the statistical analysis of samples of benthic invertebrates. Freshwater Biological Association, Sci. Publ. No. 25

Fenchel, T., Blackburn, T. H. (1979), Bacteria and mineral cycling. Academic Press, London

Gershey, R. M., Mackinnon, M. D., Williams, L. B., Moore, R. M. (1979). Comparison of three oxidation methods for the analysis of dissolved organic carbon in seawater. Mar. Chem. 7: 289-306

Godshalk, G. L., Wetzel, R. G. (1978). Decomposition of aquatic angiosperms. II. Particulate components. Aquat. Bot. 5: 301-327

Granéli, W. (1979). A comparison of carbon dioxide production and oxygen uptake in sediment cores from four south Swedish lakes. Holarc. Ecol. 2: 51-57

Hackney, C. T., de la Cruz, A. A. (1980). In situ decomposition of roots and rhizomes of two tidal marsh plants. Ecology 61: $226-231$

Hanson, R. B., Tenore, K. R. (1981). Microbial metabolism and incorporation by the polychaete Capitella capitata of aerobically and anaerobically decomposed detritus. Mar. Ecol. Prog. Ser. 6: 299-307

Hargrave, B. T. (1972). Oxidation-reduction potentials, oxygen concentration and oxygen uptake of profundal sediments in an eutrophic lake. Oikos 23: 167-177

Hargrave, B. T. (ed.) (1978). Geochemical and biological observations in intertidal sediments from Cobequid Bay, Bay of Fundy, Nova Scotia. Fish. Mar. Ser. Tech. Rep. 782

Hargrave, B. T., Phillips, G. A. (1981). Annual in situ carbon dioxide and oxygen flux across a subtidal marine sediment. Estuar. coast. Shelf. Sci. 12: 725-737

Hargrave, B. T., Prouse, N. J, Phillips, G. A., Neame, P. A. (1983). Primary production and respiration in pelagic and benthic communities at two intertidal sites in the upper
Bay of Fundy. Can. J. Fish. aquat. Sci. 40 (Suppl. 1) $229-243$

Howarth, R. W., Giblin, A. (1983). Sulfate reduction in the salt marshes at Sapelo Island, Georgia. Limnol. Oceanogr. 28: $70-82$

Howarth, R. W., Hobbie, J. E. (1982). The regulation of decomposition and heterotrophic microbial activity in salt marsh soils: a review. In: Kennedy, V. S. (ed.) Estuarine comparisons. Academic Press, London, p. 183-207

Howarth, R. W., Teal, J. M. (1979). Sulfate reduction in a New England salt marsh. Limnol. Oceanogr. 24: 999-1013

Jørgensen, B. B. (1977). The sulfur cycle of a coastal marine sediment (Limfjorden, Denmark). Limnol. Oceanogr, 22: $814-832$

Jørgensen, B. B. (1982). Ecology of the bacteria of the sulfur cycle with special reference to anoxic-oxic interface environments. Phil. Trans. R. Soc. Lond. B 298: 543-551

Jørgensen, B. B., Fenchel, T. (1974). The sulfur cycle of a marine sediment model system. Mar. Biol. 24: 184-201

Kaplan, W., Valiela, I., Teal, J. M. (1979). Denitrification in a salt marsh ecosystem. Limnol. Oceanogr. 24: 726-734

Kepkay, P. E., Novitsky, J. A. (1980). Microbial control of organic carbon in marine sediments: coupled chemoautotrophy and heterotrophy. Mar. Biol. 55: 261-266

Kepkay, P. E., Cooke, R. C., Bowen, A. J. (1981). Molecular diffusion and the sedimentary environment: results from the in situ determination of whole sediment diffusion coefficients. Geochim. cosmochim. Acta 45: 1401-1409

Mann, K. H. (1972). Macrophyte production and detritus food chains in coastal waters. Memorie Ist. ital. Idrobiol. 29 (Suppl.): 353-383

Marinucci, A. C. (1982). Carbon and nitrogen fluxes during decomposition of Spartina alterniflora in a flow-through percolator. Biol. Bull. mar. biol. Lab., Woods Hole 162: $53-69$

Mason, C. F., Bryant, R. J. (1975). Production, nutrient content and decomposition of Phragmites communis Trin. and Typha angustifolia L. J. Ecol. 63: 71-95

Nedwell, D. B. and Floodgate, G. D. (1972). Temperatureinduced changes in the formation of sulfide in a marine sediment. Mar. Biol. 14: 18-24

Odum, E. P., de la Cruz, A. A. (1967). Particulate organic detritus in a Georgia salt marsh-estuarine ecosystem. In: Lauff, G. H. (ed.) Estuaries. Am. Ass. Adv. Sci., Washington, p. 383-388

Pamatmat, M. M. (1968). Ecology and metabolism of a benthic community on an intertidal sand flat. Int. Revue ges. Hydrobiol. 53: 211-298

Pamatmat, M. M. (1977). Benthic community metabolism: a review and assessment of present status and outlook. In: Coull, B. C. (ed.) Ecology of marine benthos. University of South Carolina Press, Columbia, p. 89-111

Patriquin, D. G. (1981). The general biology of salt marshes. In: Hatcher, A., Patriquin, D. G. (ed.) Salt marshes in Nova Scotia. Institute for Resource and Environmental Studies, Dalhousie University, p. 4-27

Pomeroy, L. R., Bancroft, K., Breed, J., Christian, R. R., Frankenberg, D., Hall, J. R., Mauer, L. G., Wiebe, W. J., Wiegert, R. F., Wetzel, R. L. (1977). Flux of organic matter through a salt marsh. In: Wiley, M. (ed.) Estuarine processes, Vol. VII. Academic Press, New York, p. 270-297

Prouse, N. J., Gordon, Jr., D. C., Hargrave, B. T., McLachlan, J., Bird, C., Lakshminarayana, L., Thomas, M. (1983). Primary production: organic matter supply to ecosystems in the Bay of Fundy. MS.

Rice, D. L., Tenore, K. R. (1981). Dynamics of carbon and nitrogen during the decomposition of detritus derived 
from estuarine macrophytes. Estuar, coast. Shelf Sci. 13: $681-690$

Rich, P. H. (1979). Differential $\mathrm{CO}_{2}$ and $\mathrm{O}_{2}$ benthic community metabolism in a soft-water lake. J. Fish. Res. Bd Can. 36: $1377-1389$

Roberts, D. L. (1982). Distribution of organic carbon and nitrogen in various natural particle types of a fine intertidal sediment. M. Sc. thesis, Dalhousie University

Schwinghamer, P., Tan, F. C., Gordon, Jr., D. C. (1983). Stable carbon isotope studies on the Pecks Cove mudflat ecosystem in the Cumberland Basin, Bay of Fundy. Can. J. Fish. aquat. Sci. 40 (Suppl. 1): 262-272
Sorokin, Yu. I. (1972). The bacterial population and the process of hydrogen sulfide oxidation in the Black Sea. J. Cons. int. Explor. Mer 34: 423-454

Stainton, M. P. (1973). A syringe gas-stripping procedure for gaschromatographic determination of dissolved inorganic and organic carbon in fresh water and carbonates in sediments. J. Fish. Res. Bd Can. 30: 1441-1445

Teal, J. M., Kanwisher, J. (1961). Gas exchange in a Georgia salt marsh. Limnol. Oceanogr. 6: 388-399

Wolfe, R. S. (1971). Microbial formation of methane. Adv. microb. Physiol. 6: 107-146

This paper was presented by Professor T. Fenchel; it was accepted for printing on November 29, 1983 